\title{
Utilization of Buffalo Manure and Samosir Goat Manure on Indigofera Zollingeriana Growth
}

\author{
Indria Ningsih, E Mirwandhono, Nurzainah Ginting, Iskandar Sembiring, \\ N D Hanavy \\ Animal Production Program Study, Faculty of Agriculture, University of Sumatera Utara, Medan 20155, \\ Indonesia \\ E-mail : indrianingsih08@yahoo.com
}

\begin{abstract}
Abstrak. This study aims to look at the effect of buffalo and goat manure on the growth of Indigofera zollingeriana plants. This research was carried out in Parlondut Village, Pangururan Subdistrict, Samosir Regency, North Sumatra from March to May 2018. The design used in this study was a Completely Randomized Design with 4 replications. P0 $=$ Buffalo Cage Fertilizer 25\% $+75 \%$ Top Soil Soil, P1 = Buffalo Cage Fertilizer $50 \%+50 \%$ Top Soil Soil, P2 = Buffalo Cage Fertilizer 75\% + 25\% Top Soil Soil, P3 = $25 \%$ Goat Cage Fertilizer $+75 \%$ Top Soil Soil, $\mathrm{P} 4=$ Goat Cage Fertilizer 50\% + 50\% Top Soil Soil and P5 $=$ Goat Cage Fertilizer $75 \%+25 \%$ Top Soil Soil. The variables observed were plant height, number of leaves, number of stems, stem diameter and leaf width. The results showed that the application of manure from goats had a significant effect on the parameters of the study, namely plant height, number of leaves, number of branches and stem diameter. In conclusion, the increasing dosage of fertilization with goat manure on Indigofera zollingeriana plants, the results are getting better.
\end{abstract}

\section{Introduction}

Manure has natural properties and does not damage the soil, provides macro elements (nitrogen, phosphorus, potassium, calcium, and sulfur) and micro (iron, zinc, boron, cobalt, and molybdenium). In addition, manure functions to increase water resistance, soil microbiological activity, value of cation exchange capacity and improve soil structure. The effect of giving manure indirectly makes it easier for the soil to absorb water. The use of manure can increase the permeability and content of organic matter in the soil, and can reduce the value of soil erodobility which ultimately increases soil resistance to erosion [1]. Manure has an effect on soil fertility which is quite good because it contains complete nutrients (macro and micro) and microorganisms in it are able to decompose the soil into more mature so that some nutrients in the soil such as P are easily available to plants [2]. In organic farming activities, most farmers use manure. Manure comes from animal feces such as cattle, goats, chickens, and bat droppings. One of the livestock that has the potential as a source of organic fertilizer is goats. This is related to the advantages of manure from goat manure, which is the texture of finer and more typical goat manure. The value of the $\mathrm{C} / \mathrm{N}$ ratio of goat manure is generally still between 20 25 . Good manure must have a $\mathrm{C} / \mathrm{N}$ ratio of less than 20 , so goat manure will be better used if composted first [3].

\section{Material dan Method}

The study was conducted in the Parlondut Village, Pangururan Subdistrict, Samosir Regency, North Sumatra. This research took place from March to May 2018. The ingredients used were legumes of Indigofera zollingeriana which were 2 months old. Manure from buffalo and manure from samosir goat as a treatment of organic fertilizer on plants. Water for watering plants at the time of the study. The tools used are hoes to clean the land, loose for watering plants, measuring 
meters of cloth or rollers to measure plant height, calipers to measure stem diameter, data books, pens, calculators, plastic straps and cutter knives.

\subsection{Research Methods}

The experimental design used was a completely randomized design (CRD) with $1 / 4$ kilogram fertilizer dosage for Indigofera zollingeriana plants aged $1-8$ weeks. The treatment that will be used in this study are:

$\mathrm{P}_{1}=$ Given buffalo manure $25 \%+75 \%$ top soil

$\mathrm{P}_{2}=$ Given buffalo manure $50 \%+50 \%$ top soil

$\mathrm{P}_{3}=$ Given buffalo manure $75 \%+25 \%$ top soil

$\mathrm{P}_{4}=$ Given goat manure $25 \%+75 \%$ top soil

$\mathrm{P}_{5}=$ Given goat manure $50 \%+50 \%$ top soil

$\mathrm{P}_{6}=$ Given goat manure $75 \%+25 \%$ top soil

Where each treatment was repeated 4 times. Then the combination of treatments is:

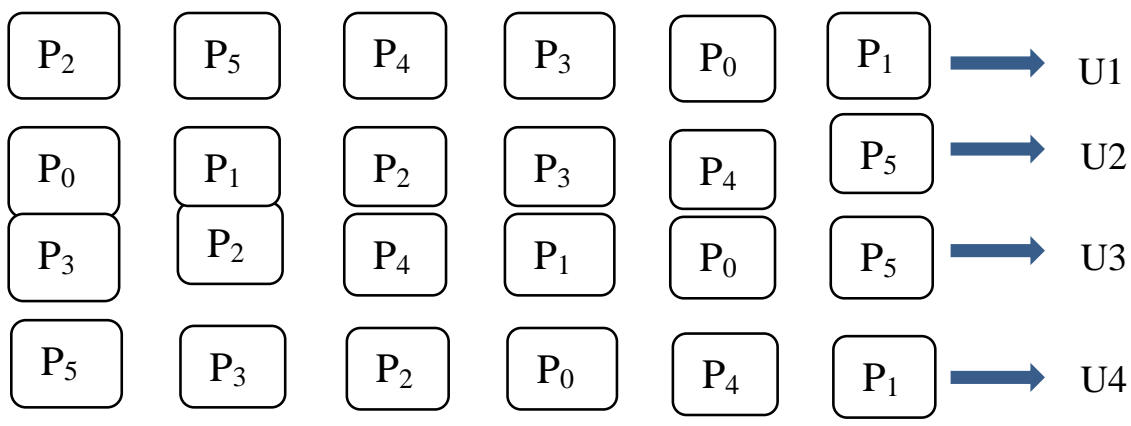

Figure 1. Scheme of research land

Information:

Plot Size $=1 \times 1.5$ meters

Spacing between plants: 2 x 2 meters

The experimental mathematical model used is the Orthogonal Contrast Design, namely:

$\mathrm{P} 0 \mathrm{P} 1 \mathrm{P} 2$ vs. P3P4P5

$\mathrm{P} 0$ vs. P1P2

$\mathrm{P} 1$ vs $\mathrm{P} 2$

$\mathrm{P} 3$ vs $\mathrm{P} 4 \mathrm{P} 5$

$\mathrm{P} 4$ vs P5

\subsection{Implementation of Research}

1. Taking buffalo and goat faeces for 3 days.

2. Making buffalo and goat manure with the first step is to take buffalo stool and goat stool (done for 3 days) then dry buffalo stools and goat feces in the shade or roof to avoid sunlight and rain, but not in places where the air circulation is lacking, then on the 30th day buffalo feces and goat stool can be used as manure.

3. Measuring the nutrient content of buffalo and goat manure for 30 days.

4. Selection of Indigofera zollingeriana seeds, the seeds used are no broken branches, leaves and height that are parallel or equal. Seeds that are good to move on beds (plots) are 2 months old.

5. Land preparation is done by way of spilling the soil first, then the shape of the beds (plots). The plot needed is 24 plots with each test carried out 6 treatments and 4 replications.

6. Provision of buffalo and goat manure is used as basic fertilizer which is given a week before planting.

7. Planting was carried out after soil extraction by giving basic fertilizer to the plot, then planting was carried out according to each treatment. 
8. Plant maintenance includes several activities including watering and weeding. 1). Watering the plants is done manually, that is by using a spout, watering is done once a day, in the afternoon especially if there is no rain so that water is available longer in the soil and avoids kelanyuan. 2). Weeding is also done manually by removing weeds around the growing plants which can cause competition in the acquisition of water and nutrients.

\subsection{Research Parameters}

The parameters in this study were plant height, number of leaves, number of branches, stem diameter, and leaf width.

\section{Results and Discussion}

3.1 Plant height

The results of research on the use of buffalo manure and goat manure on the height of the Indigofera zollingeriana plant can be seen in the following table.

Tabel 1. Average of Indigofera zollingeriana height $(\mathrm{cm})$

\begin{tabular}{llrrc}
\hline SK & Db & \multicolumn{1}{c}{ JK } & \multicolumn{1}{c}{ KT } & \multicolumn{1}{c}{ F. hit } \\
\hline Treatment & 6 & 690.9641 & 115.1606 & \\
(1). P0P1P2 vs P3P4P5 & 1 & 577.8090 & 577.8090 & $65.415^{* *}$ \\
(2). P0 vs P1P2 & 1 & 13.8770 & 13.8770 & 1.571 \\
(3). P1 vs P2 & 1 & 9.5703 & 9.5703 & 1.083 \\
(4). P3 vs P4P5 & 1 & 62.9532 & 62.9532 & $7.127^{* *}$ \\
(5). P4 vs P5 & 1 & 26.7546 & 26.7546 & $3.028^{* *}$ \\
Galat & 18 & 8.8330 & & \\
\hline Total & 23 & & & \\
\hline
\end{tabular}

In Table 1 we can see that in goat fertilizer (P3 vs. P4P5 and P4 vs P5) get better results. This is in accordance with the results of the study stating that the provision of goat manure had a significant effect on plant height, number of leaves, and stem diameter. The increase in manure dosage is directly proportional to the increase in plant height and number of leaves [4]. In Indigofera zollingeriana plants for increasing plant height growth, manure is very important for soil fertility. The most important role of manure is to improve the physical, chemical and biological properties of the soil and can make nutrients from non-available forms more available for plant growth. The addition of organic material will contribute various nutrients, especially macro nutrients $\mathrm{N}, \mathrm{P}, \mathrm{K}$, and other micro nutrients, plant growth hormones, increase the capacity to hold water, and increase the activity of soil organisms in all soil types [5].

\subsection{Number of Leaves}

The results of the research on the use of buffalo manure and goat manure on the number of leaves in the Indigofera zollingeriana plant can be seen in Table 2.

Tabel 2. The average number of leaves of Indigofera zollingeriana

\begin{tabular}{llrrc}
\hline SK & Db & \multicolumn{1}{c}{ JK } & \multicolumn{1}{c}{ KT } & \multicolumn{1}{c}{ F. hit } \\
\hline Treatment & 6 & $6,355.679$ & 115.161 & \\
(1). P0P1P2 vs P3P4P5 & 1 & $5,243.648$ & 577.809 & $23.745^{* *}$ \\
(2). P0 vs P1P2 & 1 & 183.568 & 13.877 & 0.831 \\
(3). P1 vs P2 & 1 & 63.986 & 9.570 & 0.282 \\
(4). P3 vs P4P5 & 1 & 559.459 & 62.953 & 2.533 \\
(5). P4 vs P5 & 1 & 125.017 & 26.755 & 0.566 \\
Galat & 18 & $3,975.008$ & 220.833 & \\
\hline Total & 23 & & & \\
\hline
\end{tabular}

In Table 2 it can be seen that there is no effect on buffalo and goat manure. This is in accordance with statement [6] which states that Nitrogen $(\mathrm{N})$ is the main nutrient for plant growth which is generally very necessary for the formation and growth of vegetative parts of 
plants, such as leaves, stems and roots. Solid manure from buffalo is one form of organic fertilizer that can be used to improve soil fertility, increase the content of chemical nutrients such as nitrogen, phosphate, potassium and water [7]. In Indigofera zollingeriana plants for increasing growth in the number of leaves of plants Indigofera zollingeriana, manure is very important for soil fertility. Manure can increase the availability of food (nutrients) for plants that can be absorbed from the soil. In other words, manure has the ability to change various factors in the soil, so that it can make plant growth better. $\mathrm{N}$ plays an active role in plant leaf growth [5].

3.3 Number of Branches

The results of the research on the use of buffalo manure and goat manure on the number of branches in Indifofera zollingeriana plants can be seen in Table 3

Tabel 3. Rataan jumlah cabang Indigofera zollingeriana

\begin{tabular}{llrrc}
\hline SK & Db & \multicolumn{1}{c}{ JK } & \multicolumn{1}{c}{ KT } & F. hit \\
\hline Treatment & 6 & 200.878 & 33.479 & \\
(1). P0P1P2 vs P3P4P5 & 1 & 176.719 & 176.719 & $52.392^{* *}$ \\
(2). P0 vs P1P2 & 1 & 0.753 & 0.759 & 0.225 \\
(3). P1 vs P2 & 1 & 0.031 & 0.031 & 0.093 \\
(4). P3 vs P4P5 & 1 & 21.094 & 21.094 & 6.254 \\
(5). P4 vs P5 & 1 & 2.000 & 2.000 & 0.148 \\
Galat & 18 & 60.715 & 3.373 & \\
\hline
\end{tabular}

Total 23

In Table 3 it can be seen that the provision of buffalo and goat manure together does not have a significant effect. Manure contains N, P, K refers to the growth of the number of branches. Increased vegetative value such as the number of branches caused by the role of nitrogen elements, the main role of nitrogen for plants is to stimulate overall growth, in particular, branches, stems and leaves. Plants need nutrients that fit their needs in the process of growth and development [8]. Organic materials can play a direct role as a source of plant nutrients after undergoing the mineralization process and can indirectly create a better plant growth environment by increasing nutrients to support plant growth. Organic materials can improve the physical, chemical and biological properties of the soil which in turn will improve plant growth and production so that the soil becomes more crumbly and the exchange of cations and anions becomes faster so that nutrients can be absorbed properly by plants that make plant growth good [9].

\subsection{Stem Diameter}

The results of research on the use of buffalo manure and goat manure on stem diameter in Indigofera zollingeriana plants can be seen in table 4.

Tabel 4. Average stem diameter of Indigofera zollingeriana

\begin{tabular}{lllll}
\hline SK & Db & JK & KT & F. hit \\
\hline Treatment & 6 & 6.646 & 1.274 & \\
(1). P0P1P2 vs P3P4P5 & 1 & 7.041 & 7.041 & 0.712 \\
(2). P0 vs P1P2 & 1 & 0.094 & 0.094 & 0.009 \\
(3). P1 vs P2 & 1 & 0.017 & 0.017 & 0.002 \\
(4). P3 vs P4P5 & 1 & 0.137 & 0.137 & 0.014 \\
(5). P4 vs P5 & 1 & 0.356 & 0.356 & 0.036 \\
Galat & 18 & 178.000 & 0.009 & \\
\hline Total & 23 & & & \\
\hline
\end{tabular}

In Table 4 it can be seen that giving buffalo and goat manure together has the same good results. administration of manure can improve the physical, chemical and biological properties of the soil. The results of decomposition of organic matter can improve soil structure 
to be more crumbly and loose. Soil becomes more crumb so that nutrients can be absorbed by plants well, making growth and crop yield good. Organic matter can play a direct role as a source of plant nutrients after undergoing the mineralization process and can indirectly create a better plant growth environment by increasing nutrients to support plant growth [9].

\subsection{Leaf Width}

The results of research on the use of buffalo manure and goat manure on leaf width in Indifofera zollingeriana plants can be seen in Table 5:

Tabel 5. The width of the leaves of Indigofera zollingeriana

\begin{tabular}{lllll}
\hline SK & Db & JK & KT & F. hit \\
\hline Perlakuan & 6 & 0.8515 & 0.1419 & \\
(1). P0P1P2 vs P3P4P5 & 1 & 0.6501 & 0.6501 & 0.5570 \\
(2). P0 vs P1P2 & 1 & 0.1710 & 0.1710 & 0.1465 \\
(3). P1 vs P2 & 1 & 0.0003 & 0.0003 & 0.0002 \\
(4). P3 vs P4P5 & 1 & 0.0062 & 0.0062 & 0.0053 \\
(5). P4 vs P5 & 1 & 0.0239 & 0.0239 & 0.0205 \\
Galat & 18 & 21.000 & 1.1670 & \\
\hline Total & 23 & & &
\end{tabular}

In Table 5 it can be seen that buffalo manure and goats get the same good results. Manure has properties to improve soil aeration, increase the ability of soil to retain nutrients, increase the capacity to hold water, increase soil buffering, an energy source for soil microorganisms and as a source of nutrients [10]. Goat manure has the properties of improving soil aeration, increasing the ability of soil to resist nutrients, increasing the capacity to hold water, increasing soil buffer capacity, an energy source for soil microorganisms and as a source of nutrients. Goat manure contains $\mathrm{N}$ which can encourage organs related to photosynthesis, namely leaves. Potassium acts as an activator for various enzymes involved in protein synthesis and starch. A high P element that can compose aenosine triphosphate (ATP) which directly plays a role in the process of storage and transfer of energy associated with plant metabolism and plays a role in increasing the yield component [10]. Results of Analysis of the Research and Technology Laboratory of the USU Faculty of Agriculture, 2018 Provision of goat manure has the highest $\mathrm{N}$ nutrient content of 1.82. The main role of $\mathrm{N}$ for plants is to stimulate overall growth. Manure manure has a significant effect on plant fresh weight, plant dry weight, leaf area, pod fresh weight, dry weight, number of leaves, and stem diameter. This is because the provision of manure can improve the physical, chemical and biological properties of the soil [9].

\section{Conclusion}

On the parameters of the height of goat manure plants get better results than buffalo manure but on other parameters such as (number of leaves, number of branches, stem diameter and leaf width) get good results between buffalo and goat manure in Indigofera zollingeriana plants.

\section{Referensi}

[1] Santoso, S. 2004. Kesuburan Tanah dan Pemupukan Tanah Pertanian. Pustaka Buana, Bandung.

[2] Najiyati, S. 2005. Hijauan Pakan Ternak. IPB Press, Bogor

[3] Hartatik (2006) Hartatik, W dan L.R Widowati. 2010. Pupuk Kandang. http://www.balittanah.litbang.deptan.go.id.

[4] Bara, A. and M. A. Chozin. 2009. Pengaruh Pemberian Pupuk Kandang. Dalam Kumpulan Makalah Seminar Hasil Penelitian Departemen Agronomi dan Holtikultura Fakultas Pertanian Institut Pertanian Bogor. Bogor. 
[5] Damanik, N. Suryati, A. Jekly. N. A. 2010. Pengaruh Pemakaian Berbagai Dosis Pupuk Kandang Terhadap Pertumbuhan dan Hasil Tanaman Spinach Varietas Alrite. Skripsi Fakultas Pertanian. Universitas Kristen Satya Wacana. Salatiga.

[6] Sudirja. 2007. Produksi Biji Rumput dan legum Makanan Ternak Tropik. BPFE. Yogyakarta

[7] Sarno, 2009. Pengaruh Pemberian Pupuk Kandang. Penerbit CV Yasaguna. Jakarta.

[8] Hardjowigeno, S., 2007. Ilmu Tanah. Mediyatama Sarana Perkasa, Jakarta.

[9] Odedina. 2011. Comparison of The Effectiveness of Composting for The Biological Stabilization of Cattle Manure. Chemosphere 72.

[10] Rizwan. 2008. Panduan Lengkap Budidaya Kakao. Agromedia Pustaka, Jakarta. 